\title{
Studi Literatur : Analisis Gaya Kepemimpinan Dan Kepuasan Kerja Kepala Ruangan Di Rumah Sakit
}

\section{Analysis Leadership Style and Job Satisfaction Chief of Ward at Hospitals: A Literature Review}

\author{
Firmansyah $^{1}$, Kadek Ayu Erika ${ }^{2}$, Andi Masyitha Irwan ${ }^{3}$ \\ ${ }^{1}$ Mahasiswa Magister Ilmu Keperawatan, Universitas Hasanuddin, Makassar, \\ ${ }^{2}$ Program Studi Ilmu Keperawatan, Universitas Hasanuddin, Makassar \\ ${ }^{3}$ Program Studi Ilmu Keperawatan, Universitas Hasanuddin, Makassar \\ E-mail : psmikfirmansyah@gmail.com, Samata, Gowa
}

\begin{abstract}
ABSTRAK
Salah satu pencapaian dari gaya kepemimpinan adalah kepuasan kerja. Oleh karena itu hal ini yang menjadi ketertarikan untuk dilakukan penelitian dengan menganalisa gaya kepemimpinan dan kepuasan kerja kepala ruangan pada berbagai Rumah Sakit. Tujuan dari studi literatur ini untuk mengetahui perbandingan gaya kepemimpinan dan kepuasan kerja kepala ruangan di beberapa rumah sakit dengan tipe dan status kepemilikan yang berbeda di dunia. Studi literatur ini diperoleh dari penelusuran artikel penelitian penelitian ilmiah dari rentang tahun 2011-2018 dengan menggunakan PubMed, Proquest, dan Google Schoolar. Ada 39 artikel, yang setelah dilakukan proses identification, screening dan eliglibility dari 39 artikel terdapat 10 artikel yang sesuai dengan kriteria inklusi dan sesuai dengan pertanyaan penelitian. Berbagai literatur didapatkan bahwa ada tiga gaya kepemimpinan yang diterapkan di dunia diantaranya kepemimpinan transformasional, transaksional dan laissez faire, sedangkan dari berbagai literatur menjelaskan bahwa gaya kepemimpinan yang paling banyak mempengaruhi kepuasan kerja. Gaya kepemimpinan transformasional menjadi gaya kepemimpinan yang paling banyak diterapkan di berbagai negara dan dalam studi literatur menunjukkan bahwa faktor utama yang menyebabkan ketidakpuasan kerja dan kepuasan kerja adalah gaya kepemimpinan.
\end{abstract}

Kata Kunci : Gaya Kepemimpinan, Kepuasan Kerja, Kepala Ruangan

\section{ABSTRACT}

Some studies have shown that different leadership styles will affect job satisfaction. The purpose of this literature study is to find out the comparison of leadership styles and job satisfaction by the chief of ward in several hospitals with different types and status of ownership in the world. This literature study was obtained from a search of scientific research articlesfrom the range of 2011-2018 using PubMed, Proquest, and Google Schoolar.There are 39 articles, after the identification, screening and eligibility process of 39 articles there are 10 articles that fit the inclusion criteria and are in accordance with the research questions. From various literatures, found that there were three leadership styles applied in the world including transformational, transactional and laissez faire leadership,whereas from various literatures explains that leadership style that most influences job satisfaction. Transformational leadership style becomes the most widely used leadership style in various countries and in the literature study shows that the main factors that cause job dissatisfaction and job satisfaction are leadership styles.

Keywords: Leadership Style, Job Satisfaction, Chief of Ward 
Firmansyah, Kadek Ayu Erika, Andi Masyitha Irwan : Analisis Gaya Kepemimpinan ....

\section{PENDAHULUAN}

Kepemimpinan merupakan suatu cabang ilmu yang variatif. Kepemimpinan mudah di definisikan namun dalam praktiknya sangat sulit diaplikasikan (Kartono, 2011). Dalam teori full range model of leadership ada tiga gaya kepemimpinan yaitu kepemimpinan transformasional, transaksional dan laissez faire. Kepemimpinan yang efektif adalah komponen yang paling penting yang mengarah organisasi untuk hasil yang efektif (Wong, 2007).

Gaya kepemimpinan yang efektif seperti gaya kepemimpinan tranformasional dan transaksional memiliki hubungan positif yang signifikan dengan tingkat kepuasan pasien (Lang et al, 2004). Namun, berbeda dengan laissez faire dimana seorang pemimpin dinyatakan gagal menjadi leader (Havig, 2011). Selain itu, beberapa studi telah menekankan pentingnya gaya kepemimpinan untuk kualitas pelayanan kesehatan di Rumah Sakit (Sfantou \& Loliotis, 2017).

Pola kepemimpinan akan memberikan dampak baik secara positif maupun negatif terhadap bawahannya, dampak positif diantaranya cara berfikir yang positif antara pemimpin dan bawahan, kesadaran untuk tidak melanggar komitmen, kenyamanan antara pemimpin dan bawahannya, motivasi dan kepuasan untuk terus bekerja jika memiliki model kepemimpinan transformasional dan transaksional. Dampak negative kepemimpinan seperti melahirkan sikap arogan, otoriter, komunikasi yang buruk antara pemimpin dan bawahannya, serta ketidaknyamanan dan ketidakpuasan di lingkungan kerja sehingga terjadi kegagalan dalam memimpin yang dikenal dengan laissez faire sehingga sangat signifikan untuk dianalisa gaya kepemimpinan yang dijalankan oleh kepala ruangan (Bass \& Avolio, 2012).

Menurut Gibson \& Donnelly (2002) kepuasan kerja merupakan suatu kondisi perasaan yang menyenangkan yang dihasilkan oleh para karyawan sepanjang waktu dari segi memahami pekerjaannya. Dalam sebuah riset tentang kepuasan kerja ada tiga alasan mengapa kepuasan kerja dalam organisasi penting. Pertama, terdapat bukti yang jelas bahwa karyawan yang tidak puas lebih sering melewatkan kerja dan lebih besar kemungkinan mengundurkan diri. Kedua, telah 
dibuktikan bahwa karyawan merasa puas mempunyai derajat kesehatan yang lebih baik dan usia yang lebih panjang. Ketiga, kepuasan pada pekerjaan dibawa ke kehidupan di luar pekerjaan (Robbins \& Judge, 2016).

Salah satu pencapaian dari gaya kepemimpinan adalah kepuasan kerja, gaya kepemimpinan memainkan peran penting dalam mempengaruhi kepuasan kerja baik dalam level atasan ataupun level bawahan (Voon et al, 2011). Rumah Sakit dengan tipe dan status kepemilikan yang berbeda akan berpengaruh terhadap gaya kepemimpinan yang dijalankan dan kepuasan kerja. Sebuah hasil penelitian juga menunjukkan kinerja manajer keperawatan yang berbeda-beda pada beberapa Rumah Sakit pemerintah tipe B di Jawa Barat (Yustien, 2012).

Berdasarkan berbagai penelitian tentang gaya kepemimpinan dan kepuasan kerja kepala ruangan Rumah Sakit maka sepengetahuan peneliti originalitas penelitian ini adalah belum ada studi literatur tentang gaya kepemimpinan dan kepuasan kerja kepala ruangan pada Rumah Sakit dengan tipe berbeda di berbagai negara.

Tujuan dari studi literatur ini untuk mengetahui perbandingan gaya kepemimpinan yang dijalankan oleh kepala ruangan dan kepuasan kerja sehingga menjadi sumber referensi bagi perawat tentang gaya kepemimpinan yang tepat untuk diterapkan dan indikator kepuasan kerja kepala ruangan.

\section{METODE}

Studi literatur ini diperoleh dari penelusuran artikel penelitian penelitian ilmiah dari rentang tahun 2011-2018 dengan menggunakan database PubMED, ProQuest, Google Schoolar. Pencarian pada database PubMED dengan memasukkan kata kunci pertama leadership style “OR” Leadership model (all fields) ditemukan 179 artikel, kata kunci kedua dengan memasukkan kata job satisfction “OR” work satisfaction ditemukan 38065 artikel, kata kunci ketiga dengan memasukkan kata chief of ward "OR” nurse manager ditemukan 16813 artikel, penggabungan antara kata kunci,1,2, dan 3 dengan proses filterisasi tahun 2011-2018, full text, sesuai dengan pertanyaan penelitian maka diperoleh 2 artikel penelitian. 
Pencarian pada database Google schoolar dengan memasukkan kata kuncileadership style “OR “leadership model “AND” job satisfaction "OR” work satisfction "AND” chief of ward “OR" nurse manager, dari hasil pencarian dengan menggabungkan kata kunci diperoleh 705 artikel penelitian. Pencarian pada database ProQuestdengan memasukkan kata kunci leadership style “OR “leadership model "AND” job satisfaction “OR” work satisfction ”AND” chief of ward "OR" nurse manager, dari hasil pencarian dengan menggabungkan kata kunci diperoleh 68 artikel penelitian. Hasil identifikasi ketiga database pencarian ditemukan 775 artikel penelitian dilakukan identification, screening, Eliglibility melalui kriteria inklusi dan eksklusi.

\section{HASIL DAN PEMBAHASAN}

Flow diagram pencarian literatur dilakukan pada tiga database :

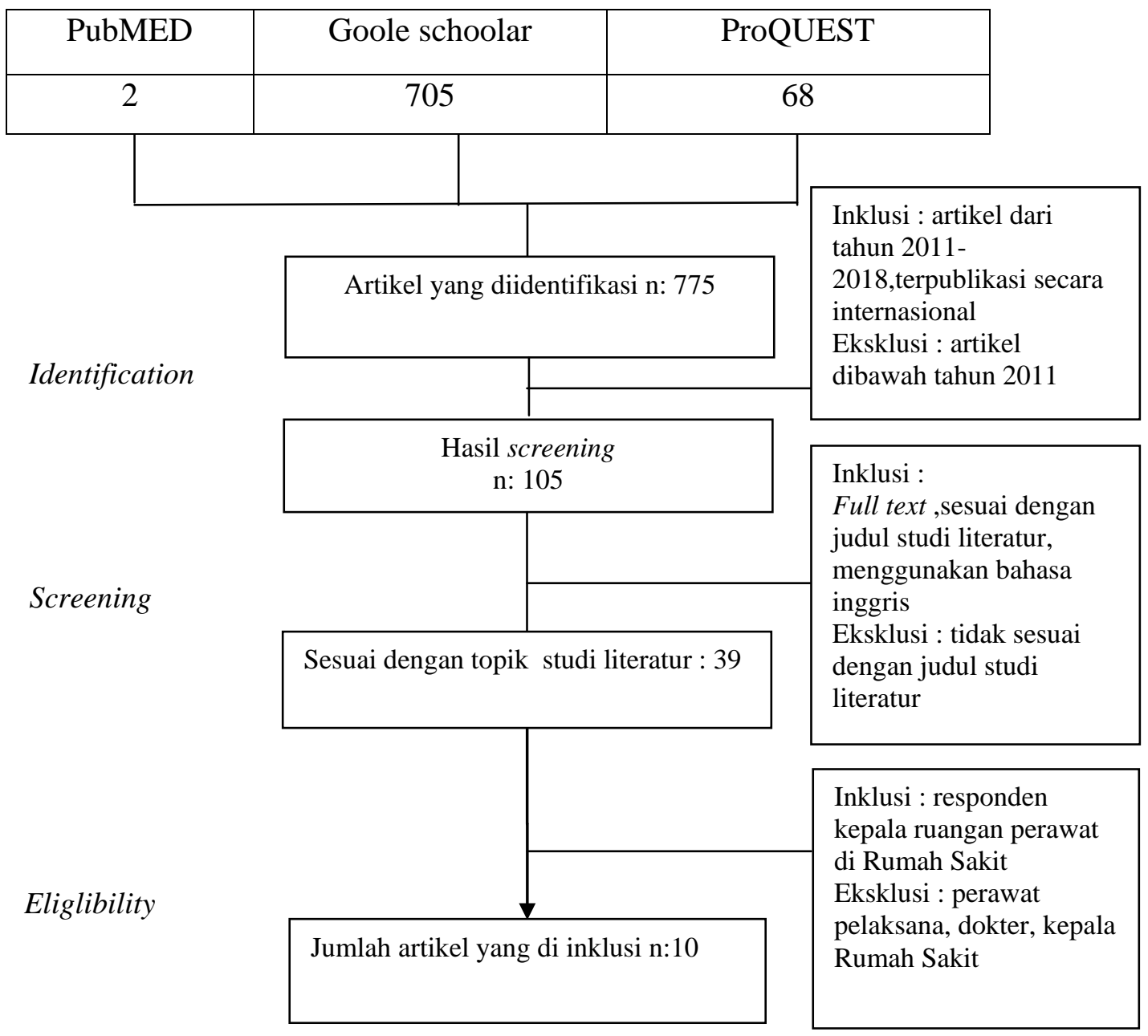

Gambar 1.1 Flow diagram pencarian literatur 
Berdasarkan hasil pencarian literatur maka didapatkan 10 artikel yang telah memenuhi kriteria inklusi. Artikel penelitian tersebut mengidentifikasi gaya kepemimpinan dan kepuasan kerja kepala ruangan di berbagai Rumah Sakit dengan status kepemilikan yang berbeda di beberapa Rumah Sakit di dunia.

Tabel 1. Analisis sintesis grid pencarian literatur

\begin{tabular}{|c|c|c|c|c|c|}
\hline No & Author & $\begin{array}{l}\text { Judul } \\
\text { Penelitian }\end{array}$ & $\begin{array}{l}\text { Metode } \\
\text { Penelitian }\end{array}$ & Instrumen & Hasil \\
\hline 1 & $\begin{array}{l}\text { Ridwan } \\
\text { Nurdin, } \\
\text { Darmawansy } \\
\text { ah, Indar } \\
2012 \\
\text { (Indonesia) }\end{array}$ & $\begin{array}{l}\text { The Influence Of } \\
\text { Leadership Style } \\
\text { And Work } \\
\text { Satisfaction On } \\
\text { Employee's } \\
\text { Performance In } \\
\text { Namlea Public } \\
\text { Hospital } \\
\text { Of Buru Regency, } \\
\text { Maluku Province }\end{array}$ & $\begin{array}{l}\text { Studi } \\
\text { kuantitatif } \\
\text { dengan } \\
\text { pendekatan } \\
\text { survey } \\
\text { analitik }\end{array}$ & $\begin{array}{l}\text { Kuesioner } \\
\text { gaya } \\
\text { kepemimpina } \\
\text { n dan } \\
\text { kepuasan } \\
\text { kerja }\end{array}$ & $\begin{array}{l}\text { Hasil distribusi } \\
\text { frequensi } \\
\text { menunjukkan kepala } \\
\text { ruangan } \\
\text { menggunakan gaya } \\
\text { kepemimpinan } \\
\text { transaksional dengan } \\
\text { nilai 73,8 \% dengan } \\
\text { indeks kepuasan kerja } \\
86,2 \%\end{array}$ \\
\hline 2 & $\begin{array}{l}\text { Warshwasky, } \\
\text { Nora \& } \\
\text { Havens } \\
\text { Donna } \\
2014 \text { (USA) }\end{array}$ & $\begin{array}{l}\text { Nurse Manager } \\
\text { Job Satisfaction } \\
\text { and intent to leave }\end{array}$ & $\begin{array}{l}\text { Studi } \\
\text { Kuantitatif }\end{array}$ & $\begin{array}{l}\text { Job } \\
\text { Satisfaction } \\
\text { electronic } \\
\text { Survei }\end{array}$ & $\begin{array}{l}\text { Hasil uji statistik } \\
\text { ANOVA,Chi Square } \\
\text { menunjukkan kepala } \\
\text { ruangan yang } \\
\text { berencana untuk } \\
\text { bekerja diatas } 5 \text { tahun } \\
\text { lebih puas dibanding } \\
\text { kepala ruangan yang } \\
\text { berencana berhenti } \\
\text { dibawahn } 5 \text { tahun } \\
\text { pekerjaannya dengan } \\
\text { nilai p<001 }\end{array}$ \\
\hline 3 & $\begin{array}{l}\text { Feather,R.A, } \\
\text { Ebrigt } \\
\text { Patricia, } \\
\text { Bakas,Tamyli } \\
\text { n } \\
2015 \\
\text { (Indianapolis, } \\
\text { USA) }\end{array}$ & $\begin{array}{l}\text { Nurse Manager } \\
\text { Behaviors that } \\
\text { RNs Perceive to } \\
\text { Affect Their Job } \\
\text { Satisfaction }\end{array}$ & $\begin{array}{l}\text { Studi } \\
\text { Kualitatif }\end{array}$ & $\begin{array}{l}\text { Lima grup } \\
\text { dengan } \\
\text { metode } \\
\text { wawancara } \\
\text { semi } \\
\text { terstruktur }\end{array}$ & $\begin{array}{l}\text { Dari hasil analisis } \\
\text { wawancara } \\
\text { diidentifikasi bahwa } \\
\text { dua faktor utama } \\
\text { yang berperan dalam } \\
\text { kepuasan kerja kepala } \\
\text { ruangan adalah } \\
\text { komunikasi dan rasa } \\
\text { hormat }\end{array}$ \\
\hline 4 & $\begin{array}{l}\text { Lorraine } \\
\text { Bormann, } \\
\text { PhD, RN, } \\
\text { MHA, CPHQ } \\
\text { Kathleen } \\
\text { Abrahamson, } \\
\text { PhD, RN } \\
\text { 2014 (USA) }\end{array}$ & $\begin{array}{l}\text { Do Staff Nurse } \\
\text { Perceptions of } \\
\text { Nurse Leadership } \\
\text { Behaviors } \\
\text { Influence Staff } \\
\text { Nurse Job } \\
\text { Satisfaction? The } \\
\text { Case } \\
\text { of a Hospital } \\
\text { Applying for } \\
\text { MagnetA } \\
\text { Designation }\end{array}$ & $\begin{array}{l}\text { Studi } \\
\text { Kuantitatif } \\
\text { dengan } \\
\text { pndekatan } \\
\text { Survei } \\
\text { analitik }\end{array}$ & $\begin{array}{l}\text { Instrumen } \\
\text { leadership } \\
\text { style MLQ( } \\
\text { Multifactor } \\
\text { leadership } \\
\text { Questionaire) } \\
-5 X\end{array}$ & $\begin{array}{l}\text { Nilai Mean } \\
\text { kepemimpinan } \\
\text { transformasional } \\
\text { pada range 0-4 adalah } \\
\text { 2,39 lebih tinggi } \\
\text { dibanding } \\
\text { kepemimpinan } \\
\text { transaksional dengan } \\
\text { nilai 2,26 }\end{array}$ \\
\hline
\end{tabular}


Firmansyah, Kadek Ayu Erika, Andi Masyitha Irwan : Analisis Gaya Kepemimpinan ....

\begin{tabular}{|c|c|c|c|c|c|}
\hline No & Author & $\begin{array}{l}\text { Judul } \\
\text { Penelitian }\end{array}$ & $\begin{array}{l}\text { Metode } \\
\text { Penelitian }\end{array}$ & Instrumen & Hasil \\
\hline 5 & $\begin{array}{l}\text { Daria M. } \\
\text { Byrne, EdD, } \\
\text { RN \& } \\
\text { Barbara N. } \\
\text { Martin, EdD } \\
2014 \text { (USA) }\end{array}$ & $\begin{array}{l}\text { Awareness and } \\
\text { Understanding of } \\
\text { the Leadership } \\
\text { Style of } \\
\text { the Nursing } \\
\text { Department Head }\end{array}$ & $\begin{array}{l}\text { Studi } \\
\text { Kuantitatif }\end{array}$ & $\begin{array}{l}\text { Instrumen } \\
\text { Leadership } \\
\text { Style } \\
\text { organizational } \\
\text { Commitment } \\
\text { and } \\
\text { Profesional } \\
\text { Satisfaction } \\
\text { Qustionairre } \\
\text { (LSOCPS) }\end{array}$ & $\begin{array}{l}\text { Pada uji statistik } \\
\text { korelasi pearson pada } \\
\text { dua gaya } \\
\text { kepemimpinan } \\
\text { terhadap kepuasan } \\
\text { kerja diidentifikasi } \\
\text { kepempimpinan } \\
\text { trasformasional lebih } \\
\text { berhubungan dengan } \\
\text { kepuasan kerja secara } \\
\text { statistik dengan nilai } \\
\text { r=0,51 }\end{array}$ \\
\hline 6 & $\begin{array}{l}\text { H. D. W. T. } \\
\text { Damayanthi } \\
2014 \text { (Sri } \\
\text { Langka) }\end{array}$ & $\begin{array}{l}\text { Leadership Style of } \\
\text { Nurse Manager }\end{array}$ & $\begin{array}{l}\text { Studi } \\
\text { kuantitatif } \\
\text { dengan } \\
\text { pendekatan } \\
\text { deksriptif }\end{array}$ & $\begin{array}{l}\text { Instrumen } \\
\text { Leadership } \\
\text { Form } \\
\text { Questionaire } \\
\text { (LFQ) dan } \\
\text { Demografic } \\
\text { Data } \\
\text { Recording } \\
\text { Form (DDRF) }\end{array}$ & $\begin{array}{l}\text { Hasil analisis pada } \\
\text { kepala ruangan } \\
\text { Gaya kepemimpinan } \\
\text { transformasional } \\
\text { (Mean- } \\
\text { 3,35,SD=0,64), } \\
\text { Kepemimpinan } \\
\text { Transaksional } \\
\text { (Mean=3,25,SD=0,45 } \\
\text { ) dengan demikian } \\
\text { gaya kepemimpinan } \\
\text { transformasional } \\
\text { lebih baik untuk } \\
\text { diterapkan }\end{array}$ \\
\hline 7 & $\begin{array}{l}\text { Cui Liu, } \\
\text { Lingjuan } \\
\text { Zhang, } \\
\text { Wenqin Ye, } \\
\text { Jianying Zhu, } \\
\text { Jie Cao, } \\
\text { Xiaoying Lu } \\
\text { and Fengping } \\
\text { Li } \\
2011 \text { (China) }\end{array}$ & $\begin{array}{l}\text { Job satisfaction } \\
\text { and intention to } \\
\text { leave: a } \\
\text { questionnaire } \\
\text { survey of } \\
\text { hospital nurses in } \\
\text { Shanghai of China }\end{array}$ & $\begin{array}{l}\text { Studi } \\
\text { Kuantitatif } \\
\text { dengan } \\
\text { pendekatan } \\
\text { cross } \\
\text { sectional }\end{array}$ & $\begin{array}{l}\text { Mueller-Mc } \\
\text { Loskey } \\
\text { Satisfaction } \\
\text { Scale }\end{array}$ & $\begin{array}{l}\text { Hasil penelitian } \\
\text { survei deskriptif 50,2 } \\
\text { merasa puas dengan } \\
\text { pekerjaannya dan } \\
\text { 40,8 tidak puas } \\
\text { dengan pekerjaannya }\end{array}$ \\
\hline 8 & $\begin{array}{l}\text { Giuliana } \\
\text { Morsiana } \\
\text { Msn, Rn, } \\
\text { Annamaria } \\
\text { Bagnasco P } \\
\text { H D , Medsc, } \\
\text { Msn, Rn } \\
\text { Loredana } \\
\text { Sasso M E D } \\
\text { S C , Msn, R } \\
\text { N , Faan } \\
\text { 2016 (Italia) }\end{array}$ & $\begin{array}{l}\text { How staff nurses } \\
\text { perceive the } \\
\text { impact of nurse } \\
\text { managers' } \\
\text { leadership style in } \\
\text { terms of job } \\
\text { satisfaction: a } \\
\text { mixed } \\
\text { method study }\end{array}$ & $\begin{array}{l}\text { Mixed } \\
\text { Method }\end{array}$ & $\begin{array}{l}\text { Instrumen } \\
\text { Multifactor } \\
\text { Leadership } \\
\text { Questionairre } \\
\text { (MLQ) dan } 3 \\
\text { grup diskusi }\end{array}$ & $\begin{array}{l}\text { Pada uji korelasi } \\
\text { spearmen } \\
\text { menunjukkan nilai p } \\
\text { value<0.01 Pada gaya } \\
\text { kepemimpinan } \\
\text { transaksional yang } \\
\text { berpengaruh pada } \\
\text { tingkat kepuasan } \\
\text { pasien }\end{array}$ \\
\hline 9 & $\begin{array}{l}\text { Usama Saleh, } \\
\text { Tom } \\
\text { O’Connor, } \\
\text { Hattan Al- } \\
\text { Subhi, Rana }\end{array}$ & $\begin{array}{l}\text { The impact of } \\
\text { nurse managers' } \\
\text { leadership styles } \\
\text { on ward staff }\end{array}$ & $\begin{array}{l}\text { Studi } \\
\text { Kualitatif } \\
\text { dengan } \\
\text { pendekatan } \\
\text { phenomenol }\end{array}$ & $\begin{array}{l}\text { Wawancara } \\
\text { semi } \\
\text { terstruktur } \\
\text { dengan } \\
\text { pertanyaan }\end{array}$ & $\begin{array}{l}\text { Hasil analisis } \\
\text { wawancara } \\
\text { menunjukkan bahwa } \\
\text { peserta } \\
\text { menggambarkan }\end{array}$ \\
\hline
\end{tabular}




\begin{tabular}{|c|c|c|c|c|c|}
\hline No & Author & $\begin{array}{l}\text { Judul } \\
\text { Penelitian }\end{array}$ & $\begin{array}{l}\text { Metode } \\
\text { Penelitian }\end{array}$ & Instrumen & Hasil \\
\hline & $\begin{array}{l}\text { Alkattan, } \\
\text { Saad Al- } \\
\text { Harbi and } \\
\text { Declan } \\
\text { Patton } \\
2018 \text { (Arab } \\
\text { Saudi) }\end{array}$ & & ogi & terbuka & $\begin{array}{l}\text { empat } \\
\text { jenis gaya } \\
\text { kepemimpinan: } \\
\text { kepemimpinan } \\
\text { relasional, } \\
\text { kepemimpinan } \\
\text { preferensial, } \\
\text { kepemimpinan rantai } \\
\text { komunikasi, dan } \\
\text { kepemimpinan yang } \\
\text { tidak efektif }\end{array}$ \\
\hline 10 & $\begin{array}{l}\text { Abdelhafidz,I } \\
\text {.M, } \\
\text { Alloubani,A. } \\
\text { M, } \\
\text { Almatari,M } \\
2015 \\
\text { (Jordania) }\end{array}$ & $\begin{array}{l}\text { Impact of } \\
\text { leadership styles } \\
\text { adopted by head } \\
\text { nurses on job } \\
\text { satisfaction : a } \\
\text { comparative study } \\
\text { between } \\
\text { govermental and } \\
\text { private hospital in } \\
\text { Jordan }\end{array}$ & $\begin{array}{l}\text { Studi } \\
\text { Kuantitatif } \\
\text { Comparative } \\
\text { study }\end{array}$ & $\begin{array}{l}\text { Instrumen } \\
\text { MLQ-5X } \\
\text { (Multifactor } \\
\text { Leadership } \\
\text { Questionairre) }\end{array}$ & $\begin{array}{l}\text { Hasil penelitian } \\
\text { menunjukkan } \\
\text { korelasi positif antara } \\
\text { gaya kepemimpinan } \\
\text { transformasional } \\
\text { dengan kepuasan } \\
\text { kerja dengan } r=0,374\end{array}$ \\
\hline
\end{tabular}

$r$ = nilai korelasi dalam uji statistik

Tabel.1 menunjukkan 10 artikel penelitian memberikan gambaran gaya kepemimpinan dan kepuasan kerja kepala ruangan dari berbagai negara. Terdapat 5 artikel yang yang menunjukkan gaya kepemimpinan transformasional yang sangat baik terhadap kepuasan kerja, terdapat 2 artikel yang menunjukkan gaya kepemimpinan transaksional yang berhubungan dengan peningkatan kepuasan kerja, dan terdapat 3 artikel yang menunjukkan gambaran kepuasan kerja kepala ruangan.

Berdasarkan hasil penelitian di salah satu Rumah Sakit di USA oleh Byrne \& Martin (2014), bahwa gaya kepemimpin transformasional memiliki pengaruh positif pada kepuasan profesional dan komitmen organisasi, sedangkan para pemimpin transaksional memiliki dampak negatif pada kepuasan profesional dan komitmen organisasi. Penelitian Damayanthi (2014) di Rumah Sakit pemerintah di Sri langka juga menunjukkan bahwa perawat di Rumah Sakit menganggap gaya kepemimpinan manajer mereka sebagai kepemimpinan transformasional sebagai gaya kepemimpinan yang efektif.

Pada penelitian lain dalam mengidentifikasi Rumah Sakit di Italia menunjukkan kepala ruangan kebanyakan mengadopsi gaya kepemimpinan 
transaksional, akan tetapi gaya kepemimpinan transformasional tetap menjadi dominan ditiru oleh kepala ruangan di dunia (Morsiana et al, 2016). Penelitian yang dilakukan di jordania menunjukkan kepala ruangan di Rumah Sakit telah menjalankan gaya kepemimpinan transformasional dan berdampak pada kepuasan kerja perawat pelaksana (Abdelhafidz et al,2015).

Hasil penelitian Bormann \& Abrahamson (2014), mengidentifikasi bahwa kepemimpinan transformasional dan transaksional berhubungan positif untuk kepuasan perawat dan kepuasan kerja secara tenaga medis di Rumah Sakit. Instrumen yang valid dalam menilai gaya kepemimpinan adalah menggunakanMultifactor Leadership Questionnaire (MLQ-5X) dimana di Arab Saudi didapatkan bahwa gaya kepemimpinan transformasional menjadi efektif bagi seorang kepala ruangan dalam menerapkan gaya kepemimpinan (Alharby, 2017).

Berdasarkan hasil penelitian Nurdin, Darmawansyah \& Indar (2012), Hasil penelitian menunjukkan bahwa gaya kepemimpinan dan kepuasan kerja berpengaruh terhadap kinerja petugas di RSUD Namlea. Variabel yang paling besar pengaruhnya terhadap kinerja karyawan adalah variabel gaya kepemimpinan. Pada penelitian Totononu \& Dwiantoro (2017), menunjukan bahwa gaya kepemimpinan transformasional memiliki pengaruh dan dampak terhadap kepuasan kerja perawat sehingga banyak yang menggunakan gaya kepemimpinan ini dalam suatu organisasi yang dipimpinnya, dimana dengan gaya kepemimpinan transformasional maka akan meningkatkan kepuasan kerja perawat dan juga berkontribusi pada peningkatan retensi perawat serta memiliki niat untuk tetap kerja.

Pada penelitian Petrosova \& Pokhilenko (2015), di Finlandia mengidentifikasi faktor-faktor yang mempengaruhi kepuasan kerja dan ketidakpuasan dari kepala ruangan ditentukan dalam enam hal : kondisi kerja, dukungan, peluang untuk pengembangan profesional, otonomi dan pengambilan keputusan, kekuasaan, dan stres. Kepuasan kerja manajer keperawatan dapat ditingkatkan dengan memastikan aman dan memungkinkan lingkungan kerja, pengurangan beban kerja, rentang kendali, dan stres, memberikan akses ke 
sumber daya, tenaga, dan informasi, menerapkan model manajemen, memberikan peluang bagi profesional dan pengembangan pendidikan.

Hasil penelitian di China menunjukan sebagian besar ketidakpuasan perawat di Shanghai dalam bekerja dipengaruhi oleh gaji, interaksi, reward,dan tanggung jawab atasan merupakan faktor yang signifikan menjadi penyebab perawat di China berniat meninggalkan tempat kerja dan tidak puas (Liu et al, 2016). Pada penelitian lain angka kepuasan kerja kepala ruangan dan perawat di Rumah Sakit di Amerika Serikat sangat dipengaruhi oleh komunikasi dan rasa hormat yang tinggi antara atasan dan karyawan (Feather et al,2015).

\section{PEMBAHASAN}

Pada penelitian yang dilakukan oleh Negussie \& Demissie (2013) mengidentifikasi bahwa perawat pelaksana merasa lebih puas dengan gaya kepemimpinan transformasional sehingga diharapkan kepala ruangan untuk menggunakan gaya kepemimpinan transformasional dalam meningkatkan kepuasan kerja. Gaya kepemimpinan transformasional merupakan satu bentuk kepemimpinan modern (Bushra et al, 2011), dimana mampu meningkatkan atau membawa perubahan yang positif bagi para bawahannya melalui metode penyelesaian masalah yang efektif (Riaz et al, 2011).

Penelitian yang dilakukan Abdelhafiz et al (2016) mengidentifikasi bahwa gaya kepemimpinan transformasional mampu berkontribusi dalam peningkatan retensi perawat, hal ini sejalan dengan penelitian yang dilakukan Abualrub et al (2011) bahwa dengan menerapkan kepemimpinan transformasional menjadikan perawat lebih termotivasi dalam bekerja serta menurut Alsharani (2016) mampu meningkatkan kinerja bawahannya. Pada literatur lain kepemimpinan transformasional menitikberatkan pada tanggung jawab yang tinggi, penyelesaian masalah secara persuasif, pemberian reward, penghargaan dan motivasi antara pemimpin terhadap bawahannya (Javed et al, 2014).

Indikator kepuasan kerja setiap orang berbeda. Berdasarkan sebuah penelitian menunjukan bahwa faktor utama yang menyebabkan ketidakpuasan kerja dan kepuasan kerja adalah gaya kepemimpinan (Asmuji, 2012), adapun faktor lain dalam penelitian yang menjadi indikator kepuasan kerja adalah 
penghasilan yang rendah, tekanan yang tinggi,tidak adanya reward hingga hubungan yang tidak sinergi dengan pimpinan (Sunyoto, 2012).

Menurut Riggio (2011), peningkatan kepuasan kerja dapat dilakukan dengan cara sebagai berikut: melakukan perubahan dalam struktur kerja, seperti melakukan rotasi pekerjaan yaitu sebuah sistem perubahan posisi pekerjaan dari satu posisi tugas ke tugas lainnya, melakukan perubahan pada struktur pembayaran gaji, perubahan sistem pembayaran ini dilakukan dengan berdasarkan pada keahlian, pemberian jadwal kerja yang fleksibel, dengan memberikan kontrol pada para pekerja mengenai pekerjaan sehari-hari mereka yang terpenting bagi mereka yang bekerja di daerah padat, perusahaan mengadakan program yang dianggap mampu meningkatkan kepuasan kerja para karyawan misalnya: health center, profit sharing, dan employee sponsored child care.

\section{SIMPULAN}

Gaya kepemimpinan yang dominan dijalankan oleh kepala ruangan di beberapa negara di dunia adalah gaya kepemimpinan transformasional yang berdampak positif terhadap kepuasan kerja kepala ruangan dan perawat di rumah sakit. Gaya kepemimpinan tranformasional yang dijalankan menjadi suatu ukuran bagi kepala ruangan di Rumah Sakit sebagai barometer kesuksesan dalam memimpin sehingga menjadi referensi bagi pemimpin dalam aspek manapun untuk menggunakan gaya kepemimpinan ini. Kepuasan kerja kepala ruangan dan perawat di rumah sakit sangat dipengaruhi oleh gaya kepemimpinan atasan terhadap bawahannya sehingga antara gaya kepemimpinan dan kepuasan kerja merupakan dua hal yang berbanding lurus.

\section{UCAPAN TERIMA KASIH}

Peneliti mengucapkan terimakasih kepada Program Studi Ilmu Keperawatan, Universitas Hasanuddin, Makassar

\section{DAFTAR PUSTAKA}

Abualrub R.F. \& Alghamdi M.G. (2011): The impact of leadership style on nurses' satisfaction and intentio to stay among Saudi nurses. Journal Of Nursing Management. Saudi Arabia.Volume(issue):1-11. 
Abdelhafiz, I.M., Alloubani, A.M., \& Almatari, M. (2016): Impact of leadership style adopted by head nurses on job satisfaction: a comparative study between governmental and private hospitals in Jordan. Juornal Of Nursing Management. Saudi Arabia.Volume(issue):384-392.

Alharby, A. Y. (2017). Leadership styles of Nurse manager and their effect on nurse and organisational performance,issue, and problems. international journal of information research and review, Volume(issue):4(09) 5164525 September 2017.

Alshahrani, F.M., \& Baig, L.A., (2015): Effect of leadership style on job satisfaction among critical care nurses in Aseer, Saudi Arabia. Journal of the College ofphysicians and Surgeons Pakistan, Volume(issue): 26(5).366370.

Asmuji.(2012).Manajemen Keperawatan.Jakarta:Arruz media

Bass, B.M. \& Avolio, B.J.(2006). Bass \& stodghill's handbook of leadership: Theory, Research, and Managerial Aplication $3^{\text {rd }}$ ed.New York: Free Press

Bormann, L., \& Abrahamson, K. (2014). Do staff perceptions of nurses leadership behaviours influence staff nurse job satisfaction the case of hospital applyng for magneta designation. JONA Volume 44 Copyroght B 2014 Wolters Kluwer Health Lippincot William \& wikins

Bushra, F., Usman, A., \& Naveed, A. (2011): Effect of Transformational Leadership on Employees' Job Satisfaction and Organizational Commitment

in Banking Sector ofLahore (Pakistan). International Journal of Business and Social Science. Lahore, Pakistan. Volume(isue):2(08).

Byrne, D. M., \& Martin, B. N. (2014). Awareness and understanding of the leadership style of the nursing departemen head. Journal of Nurse educator Vol 39 No.3 Copyright 2014 wolters kluwert health Lippincot william \& wikins. Volume(issue):39(3)

Damayanthi, H. (2014). Leadership Style of Nurse Manager. International journal of scientific and research publications volume 4, issue 8 August 2014 ISSN 2250-3153.

Feather,R.A, Ebrigt Patricia, Bakas,Tamylin.(2015).Nurse Manager Behaviors that RNs Perceive to Affect Their Job Satisfaction.Journal of Nursing Forum an independent voice of Nursing Volume 50 Issue.2 Page 220-229 2015

Gibson, J.L., \& Donnelly, J.H. (2002). Organisasi Perilaku, Struktur dan proses. Jilid 1, Jakarta: Erlangga.

Havig, A.; Skogstad, A.; Kjekshus, LA; Romoren. (2011) LE Leadership, staffing and quality of care in nursing homes. BMC Health Serv. [CrossRef] [PubMed].Volume 2, Issue 10 Page 101-111

Javed, H. A., Jaffari, A. A., \& Rahim, M. (2014): Leadership style and employees' job satisfaction: A case from the private Banking sector of Pakistan. Journal of Asian Business Strategy. Pakistan. Volume 9.issue 06 Page 41-50.

Kartini,Kartono.(2011).Pemimpin dan Kepemimpinan.Jakarta: Rajawali Grafindo Persada 
Lang, TA; Hodge, M.; Olson, V.; Romano, PS; Kravitz, RL.(2004). Nurse-patient ratios: A systematic review on the effects of nurse staffing on patient, nurse employee and hospital. J. Nurs. Adm., Volume 34.Issue 04,Page 326-337. [CrossRef] [PubMed]

Liu, C., Zhang, L., Yee, W., \& Zhu, J. (2011). Job Satisfaction and intention to leave:a questionaire survei of hospital nurses in Shanghai of China. Blackwell publishing Ltd.Journal of Clinical Nursing, Volume 21,Issue 12,255-263 255 DOI:10.1111/J.13652702.201.03766.X .

Morsiana, G., Bagnasco, A., \& Sasso, L. (2016). How staff nurses perceive the impact of nurse manager leadership style in terms of job satisfaction: a mixed method study. Journal of Nursing Management. Volume 23, Issue 03. DOI:10.1111/jonm.12448.

Mrayyan, M. T. (2011). Nurse job satisfaction and retention: comparing public with private hospitals in. Journal of Nursing Management, Volume 13, Issue 8, Page 40-50.

Negussie, N. \& Demissie, A. (2013): Relationship between leadership style of nurses managers and nurses' job satisfaction in Jimma University Specilialized Hospital. Ethiopia J Health Sci. Vol. 1, No. 03. Page 49-58

Nurdin, R., Darmawansyah, \& Indar. (2012). The influence of leadership style and work satisfaction on employes's performance in Namlea Public Hospital of Buru Regency, Maluku Province. Journal kesehatan masyarakat universitas Hasanuddin, Volume 9.Issue 01 Page 01-09.

Petrosova, L., \& Pokhilenko, I. (2015). Job satisfaction of nursing manager. publication Bachelor's nthesis jamk university.Journal of Nursing Management and leadership.Volume 06.Issu 02.Page 20-31

Robbins, S.P \& Timothy A. J (2016). Perilaku Organisasi Edisi 16, PT. Salemba Empat : Jakarta.

Riaz, T., Akram M.U., \& Ijaz H. (2011). Impact of Transformational Leadership Style on Affective Employees' Commitment: an Empirical Study of Banking Sector in Islamabad (Pakistan). The Journal of Commerce. Volume (Issue) 3(1), page 43-51

Riggio, R, E (2011). Introduction to industrial/ organizational psychology. (5th Edition). New Jersey: Pearson Education

Saleh, U., O'Conner. T., Al-Subhi, H., Al Kattan. R, Al-Harbi.S, Patton.D.(2018). The Impact of nurse manager leadership style on ward staff. British journal of Nursing 2018 volume 27 No.4.Page 197-203

Sfantou, D. F., Laliotis, A., Patelarou, A. E., Sifaki- Pistolla, D., Matalliotakis, M., \& Patelarou, E. (2017). Importance of Leadership Style towards Quality of Care Measures in Healthcare Settings: A Systematic Review. Healthcare, Volume (Issue) 5(4), $\quad$ Page 73. http://doi.org/10.3390/healthcare5040073

Sunyoto.(2012).Manajemen Sumber Daya Manusia.Jakarta:PT BukuSeru

Totonou, A. E., \& Dwiantoro, L. (2017). Gaya kepemimpinan yang dapat meningkatkan kepuasan kerja perawat. jurnal keperawatan universitas Diponegoro.Volume 04.Issue 09 Page:07-13 
Voon M.L et al.(2011).The influence of leadership styles on employees' job satisfaction in public sector organization in Malaysia. International Journalof Business, Management and Social Sciences. Vol.2, No.1, Page 24-32

Warshwasky, N. E \&Havens,D.S.(2014).Nurse Manager Job Satisfaction and Intent leave.NIH Public Access Author Manuscript Nurs Econ Volume 31 Issue 01 Page 32-39 PMID: 24689156

Wong, CA; Cummings, GG The relationship between nursing leadership and patient outcomes:A systematic review. J. Nurs. Manag. 2007, 15, 508-521. [CrossRef] [PubMed

Yustien, R. (2012). Pengaruh penerapan sistem pengendalian manajemen pada pusat pendapatan dan biaya terhadap kinerja manajerial rumah sakit umum tipe B di provinsi Jawa Barat. Jurnal pendidikan ekonomi dan bisnis. Volume 04 Issue 01.Hal:44-53. 